\title{
WPŁYW SKŁADNIKÓW DIETY ORAZ AKTYWNOŚCI FIZYCZNEJ NA STAN KOŚĆCA OSÓB STARSZYCH
}

\section{THE IMPACT OF DIET COMPONENTS AND PHYSICAL ACTIVITY ON THE SKELETON OF OLDER PEOPLE}

\author{
Dorota Gumiela ${ }^{1,2, a}$, Daria Dudek ${ }^{1, b}$ \\ ${ }^{1}$ studentka dietetyki, Instytutu Żywienia Człowieka i Dietetyki, Uniwersytet Przyrodniczy w Poznaniu \\ ${ }^{2}$ Katedra i Zakład Biochemii i Biologii Molekularnej, Uniwersytet Medyczny im. Karola Marcinkowskiego w Poznaniu \\ ${ }^{\text {a }}$ https://orcid.org/0000-0003-3452-8746 \\ ${ }^{\mathrm{b}}$ https://orcid.org/0000-0003-1912-839X
}

DOI: https://doi.org/10.20883/pielpol.2019.42

\begin{abstract}
STRESZCZENIE
Wraz ze starzeniem się społeczeństwa osteoporoza staje się istotnym problemem, o którym powinno się mówić i edukować ludzi, w jaki sposób jej zapobiegać. Osteoporoza jest chorobą szkieletu, w której dochodzi do obniżenia gęstości mineralnej kości (BMD). W celu zapobiegania osteoporozie konieczna jest podaż odpowiednio zbilansowanej diety - wapnia, witaminy $\mathrm{D}, \mathrm{K}$, białka, wielonienasyconych kwasów tłuszczowych omega-3 oraz codzienna aktywność fizyczna. Aktywność fizyczna w dzieciństwie jest istotnym czynnikiem dla zachowania masy kostnej w wieku starczym. Według WHO osoby powyżej 65 r.ż. powinny wykonywać 150 minutowy trening aerobowy lub 75 minut intensywnej aktywności fizycznej. U osób, u których wystąpiła osteoporoza wykazano, iż suplementacja wapniem (1200 mg/dobę) i witaminą D (800 IU/dobę) zapobiega złamaniom szyjki kości udowej oraz utrzymuje odpowiednią gęstość mineralną kości. Należy jednak kontrolować spożycie fosforu, który może spowodować wydalanie wapnia wraz z moczem, co wpływa niekorzystnie na stan kośćca. Stosunek spożycia wapnia do fosforu powinien wynosić 1:1. Odpowiednio zbilansowana dieta jest w stanie pokryć zapotrzebowanie na kluczowe składniki wspomagające profilaktykę osteoporozy tj. witamina K oraz kwasy omega-3. W momencie, gdy dojdzie do zachorowania na osteoporozę zadaniem pielęgniarki jest uśmierzenie bólu pacjenta i sprawowanie kontroli nad prawidłowym przebiegiem rehabilitacji pacjenta.
\end{abstract}

SŁOWA KLUCZOWE: osteoporoza, styl życia, żywienie, dieta, aktywność fizyczna.

\section{Wstęp}

Światowa Organizacja Zdrowia (WHO) definiuje osteoporozę jako stan obniżenia gęstości mineralnej kości (BMD - bone mineral density) poniżej 2,5 odchyleń standardowych (T-score <-2,5) w stosunku do wartości dla populacji ludzi zdrowych [1]. Zmienność międzyosobnicza w gęstości mineralnej kości jest

\begin{abstract}
With aging, osteoporosis is an important issue that should be addressed and educated on how to prevent it. Osteoporosis is a skeletal disease in which bone mineral density (BMD) is reduced. In order to prevent osteoporosis it is necessary to supply a properly balanced diet - calcium, vitamin $D, K$, protein, polyunsaturated omega-3 fatty acids and daily physical activity. Physical activity in childhood is an important factor for maintaining bone mass in the old age. According to WHO, people over the age of 65 should exercise 150 minutes of aerobic training or 75 minutes of intense physical activity. People with osteoporosis have been shown to have calcium supplements (1200 mg/day) and vitamin D (800 IU/day) to prevent fractures of the femoral neck and maintain adequate bone mineral density. However, you should control the intake of phosphorus, which may cause calcium excretion along with urine, which adversely affects the state of the skeleton. The ratio of calcium to phosphorus should be 1: 1 . Properly balanced diet is able to cover the need for key ingredients that help prevent osteoporosis, i.e. vitamin $\mathrm{K}$ and omega-3 fatty acids. At the moment when it comes to osteoporosis, the nurse's task is to relieve the patient's pain and control the correct course of the patient's rehabilitation.
\end{abstract}

KEYWORDS: osteoporosis, lifestyle, nourishment, diet, physical activity.

genetycznie określona, czynniki stylu życia, w tym żywienie oraz ćwiczenia są modyfikowalnymi parametrami wpływającymi na ich masę [2]. W wyniku osteoporozy może dochodzić do złamań osteoporotycznych, które obejmują zwykle szyjkę kości udowej, kręgi i kości przedramienia. Wtórnie złamania przyczyniają się do odczuwania przewlekłego bólu, niepeł- 
nosprawności i upośledzenia jakości życia pacjentów z osteoporozą. Szacuje się, że w Unii Europejskiej do 2025 roku więcej niż 30 milionów kobiet i mężczyzn w wieku 65 lat będzie dotkniętych osteoporozą. Odpowiednie metody zapobiegawcze mogą obniżyć koszty i pozwolić zachować jakość życia [3]. Narodowa Fundacja Osteoporozy (National Osteoporosis Fundation) zaleca interwencję w celu zmniejszenia ryzyka zachorowania: odpowiednio zbilansowaną dietę, w tym odpowiednie spożycie wapnia i witaminy $\mathrm{D}$, regularną aktywność fizyczną, zaprzestanie palenia tytoniu, ograniczenie alkoholu do 2-3 drinków dziennie [4].

Celem pracy jest ocena wpływu składników diety oraz aktywności fizycznej na stań kośćca osób starszych.

\section{Wpływ witaminy D na stan kośćca}

Utrzymanie odpowiedniego poziomu witaminy D u starszych osób zmniejsza ryzyko obniżonej gęstości mineralnej kości oraz złamań osteoporotycznych [2]. Witamina $D$ dostarczana jest wraz z dietą w postaci ergokalcyferolu $\left(D_{2}\right)$ oraz cholekalcyferolu $\left(D_{3}\right)$. Syntetyzowana jest również w skórze jako 7-dehydrocholesterol w wyniku ekspozycji na promienie słoneczne i dzięki temu pokrywa prawie $80 \%$ zapotrzebowania. Jednak w okresie zimowym witamina ta powinna być dostarczana z żywnością, gdyż czas przebywania na świeżym powietrzu jest krótki oraz ekspozycja skóry na promienie słoneczne jest minimalna [5]. Produkty, które zawierają odpowiednią ilość tej witaminy to tłuste ryby, tj. makrela, halibut, łosoś oraz oleje z ich wytworzone [6]. Witamina D przyczynia się do zwiększeniu wchłaniania wapnia oraz zmniejszeniu poziomu parathormonu. U osób w wieku podeszłym o 30\% zmniejszają się zapasy 7-dechydrocholesterolu w narządach, obniża się również hydroksylacja $25(\mathrm{OH}) \mathrm{D}_{3}$ do $1,25(\mathrm{OH}) \mathrm{D}_{3}$ w nerkach, upośledzeniu ulega funkcja receptorów (VDR) dla witaminy D w narządach [5]. Norma spożycia witaminy tej u osób w wieku 50-70 lat wynosi $15 \mu \mathrm{g} / \mathrm{dzień,} \mathrm{jednak}$ powyżej 70 roku życia poziom jej wzrasta do wartości $20 \mu \mathrm{g} / \mathrm{dzień}$. Podczas leczenia osteoporozy dzienna dawka powinna wynosić 1000 IU co odpowiada $25 \mu \mathrm{g}$ [6]. W badaniu przekrojowym, w którym brały udział 63 starsze kobiety chorujące na osteoporozę (w wieku 60,6 \pm 3,1 lat), przeprowadzono test Timed Up and Go w celu pomiaru mobilności funkcjonalnej i równowagi postawy ciała ocenianą na platformie przenośnej AccuSway Plus. Maksymalną wytrzymałość badano przy użyciu isokinetycznego dynamometru dla zgięcia i wyprostowania kolan. Grupa została podzielona na kwantyle zgodnie z zawartością witaminy D w surowicy krwi. Poziom witaminy był niezależnie związany z testem Time Up and Go $(p=0,001)$. Nie stwierdzono różnic pomiędzy zmiennymi demograficznymi oraz kliniczny- mi lub w równowadze ciała. Jednakże znaczne różnice zaobserwowano w teście Time Up and Go, a grupa o najwyższym poziomie witaminy D wykazała istotnie lepsze wyniki niż grupa o jej najniższej wartości ( $p=0,001)$. Poziom witaminy $D$ w surowicy był niezależnie związany z wytrzymałością kolan i ich funkcjonalną mobilnością u kobiet po menopauzie zmagających się z osteoporozą [8]. Suplementacja witaminą D zmniejsza ryzyko złamań oraz częstotliwość upadków u osób starszych. Podczas podawania jej zdrowym osobom w wieku 65 lat i starszym w dawce 17,5 $\mu \mathrm{g}$ przy współudziale podaży wapnia w ilości 500 mg dziennie wskaźnik ryzyka złamań zmniejszył się o 50\% w ciągu 3 lat, wykluczając złamania kręgosłupa [5]. W badaniach zaobserwowano redukcję złamań szyjki kości udowej o 52\% oraz - 32\% poza obszarem kręgosłupa u starszych kobiet o średniej wieku 84 lata, w wyniku leczenia wapniem oraz witaminą D przez 36 miesięcy odpowiednio w dawkach $1200 \mathrm{mg} /$ dobę oraz 800 IU. Natomiast według Dawson-Hughes zarówno kobiety, jak i mężczyźni po 65 r.ż. suplementujący $700 \mathrm{IU}$ witaminy D oraz $500 \mathrm{mg}$ wapnia na dobę w porównaniu z grupą placebo, wykazali zmniejszoną częstość złamań poza kręgosłupem o 58\% [7].

\section{Wpływ wapnia na stan kośćca}

Wapń jest podstawowym składnikiem mineralnym kości. W ludzkim organizmie występuje w ilościach 10001200 g, z czego aż 99\% kumulowane jest w strukturach kości, zębów oraz paznokci w postaci węglanów i fosforanów wapnia. W celu zapobiegania osteoporozie należy spożywać odpowiednią ilość wapnia [9]. Normy spożycia tego składnika dla kobiet oraz mężczyzn w wieku 66-75 lat oraz > 75 r.ż. wynoszą 1200 mg/dobę [10]. Całodzienne zapotrzebowanie na wapń najłatwiej pokryć spożywając produkty mleczne. Laktoza w nich zawarta wpływa korzystnie na jego zwiększone przyswajanie. Jednak osobom borykającym się z nietolerancją laktozy zaleca się spożywanie fermentowanych produktów spożywczych, tj. kefir, maślanka lub sery podpuszczkowe. Roślinnymi źródłami wapnia są również warzywa kapustne: jarmuż, brukselka, kapusta, brokuły oraz rośliny strączkowe, tj. fasola, soja i soczewica [5]. Do czynników zwiększających wchłanianie wapnia należą: kwas żołądkowy, odpowiedni stosunek wapnia do fosforu, witamina D oraz obecność laktozy w diecie. Antagonistycznie natomiast działają: niskie pH treści żołądkowej, nadmierne spożycie żelaza i magnezu, niedoborowa ilość witaminy D w diecie oraz obecność w niej fitynianów i szczawianów. Po spożyciu tego składnika aż $60 \%$ wydalane jest z kałem, natomiast jedynie $30 \%$ wchłaniane jest w jelicie cienkim oraz $10 \%$ w jelicie grubym [5]. 
W patogenezie osteoporozy należy zwrócić uwagę na niedostateczną podaż wapnia w diecie lub jego upośledzone wchłaniania w obrębie jelita cienkiego. Wchłanianie odbywa się poprzez dwa mechanizmy: podczas niskiej podaży tego składnika uruchamiany jest aktywny transport przez błonę śluzową jelit, który zależny jest od aktywnej postaci witaminy D $\left[1,25-(\mathrm{OH})_{2}\right.$ cholekalcyferol] oraz przy zwiększonej podaży wapnia wchłaniany na drodze dyfuzji i w tym wypadku od niej niezależny. Jednak mechanizm adaptacyjny polegający na zwiększonym wchłanianiu wapnia z organizmu przy jego niedoborze w diecie u osób w wieku starszym nie przynosi zadowalających rezultatów, jest on niedostateczny dla utrzymania odpowiedniego bilansu wapnia w organizmie [9]. W badaniu kohortowym Włodarka i wsp. [11] (2012) określono wpływ spożycia wapnia na zmiany w gęstości mineralnej kości udowej oraz częstość występowania jej złamań u kobiet w wieku powyżej 55 r.ż. Brało w nim udział 625 kobiet losowo rekrutowanych z ogólnej populacji. Średnie spożycie wapnia z produktów mlecznych było niższe w grupie kobiet z występującym złamaniem szyjki kości udowej w porównaniu z grupą bez oznak choroby (275 mg vs 383 mg). Podobną zależność zaobserwowano u kobiet z wcześniejszymi złamaniami szyjki kości udowej w porównaniu z grupą, w której incydenty te nie występowały (336 mg vs 395 mg) [11]. W metaanalizie przeprowadzonej przez Tang i wsp. (2007) uwzględniono 29 badań, w których wzięto pod uwagę suplementację samego wapnia (200-1600 mg/dobę) lub wapnia z witaminą D (200-800 IU/dobę), jednak wykluczono badania, w którym suplementowana była tylko witamina D. Łączna liczba osób biorących udział wynosiła 63 897, z czego $92 \%$ stanowiły kobiety oraz średni wiek badanych określono na 68 lat. Po okresie 3,5 lat badane grupy porównano z grupą placebo i otrzymano znaczące różnice, m.in. ryzyko złamań kości zmniejszyło się o 12\%, zmniejszyła się utrata gęstości kości o 0,54\% bliższego odcinka kości udowej oraz odcinka lędźwiowego kręgosłupa o 1,19\%. Statystycznie większy efekt leczniczy zaobserwowano w podgrupach, w których wyjściowy poziom wapnia był poniżej $700 \mathrm{mg} /$ dobę oraz u osób w wieku powyżej 70 r.ż. suplementujący go w dawce nie niższej niż 1200 mg/dobę. Metaanaliza ta stała się podstawą do stworzenia zaleceń dla mężczyzn powyżej 65 r.ż. oraz kobiet po menopauzie do przyjmowania wapnia ogółem w ilości 1200 mg/dobę i 800-1000 IU witaminy $\mathrm{D}$ na dobę [7].

\section{Wpływ fosforu na stan kośćca}

Fosfor jest drugim obok wapnia podstawowym składnikiem tkanki kostnej. W organizmie człowieka występuje w ilości 550-770 g, z czego prawie 85\% jest magazyno- wane w kościach i zębach w postaci fosfoprotein oraz kryształów hydroksyapatytów, kolejne 14\% w mięśniach oraz $1 \%$ we krwi. llość tego składnika regulowana jest poprzez kalcytriol oraz parathormon w organizmie. Normy spożycia fosforu dla kobiet w wieku 50-70 lat oraz powyżej 70 r.ż. wynoszą $700 \mathrm{mg} /$ dobę [6]. Składnik ten występuje w znacznej ilości w żywności, w związku z tym niedobory z nim związane praktycznie nie występują, jednak należy zwracać uwagę na jego nadmierne spożycie [6]. Do żywności bogatej w fosfor należy m.in.: mięso, ryby, jaja, orzechy, produkty mleczne, produkty zbożowe oraz napoje gazowane. Występuje również grupa produktów, do których jest on dodawany są to m.in. przetwory mięsne, zupy w proszku, koncentraty oraz dania typu fast food [5]. Nadmierne spożycie fosforu może wywołać poważne konsekwencje, tj. wydalanie wapnia z moczem, biegunki, zmniejszenie przyswajalności żelaza, cynku oraz miedzi lub zwapnienie organów i tkanek miękkich. Przed 50-55 r.ż. stosunek wapnia do fosforu powinien być ściśle kontrolowany i wynosić 1:1 [6]. W badaniu przeprowadzonym w Korei z udziałem 10 tysięcy osób, wykorzystując wskaźnik BMD do określenia zależności wykazano, że ryzyko osteoporozy jest tym większe, im mniejszy jest stosunek wapnia do fosforu w diecie [12].

\section{Wpływ witaminy K na stan kośćca}

Witamina $\mathrm{K}$ odnosi się do strukturalnie podobnych związków, rozpuszczalnych w tłuszczach. Naturalnie witamina $\mathrm{K}$ występuje $\mathrm{w}$ formie filochinonu $\mathrm{K}_{1}$ i menachinonu $\mathrm{K}_{2}(\mathrm{MK})$. Witamina $\mathrm{K}_{1}$ jest syntezowana $\mathrm{w}$ roślinach, które stanową jej główne źródło w diecie człowieka. Główne źródło witaminy $\mathrm{K}_{1}$ stanowią zielone warzywa, niektóre owoce (np. awokado, kiwi, zielone winogrona) [13]. Witamina $\mathrm{K}_{2}$ (oznaczana symbolem MK, przy którym dodaje się odpowiednią liczbę jednostek izoprenoidowych (1-13)) [14] jest syntezowana przez bakterie (z wyjątkiem MK-4) i znajduje się w niektórych serach, mięsach, rybach, nabiale, jajach i sfermentowanej żywności. Inne formy, takie jak MK-10 i MK-13, są wytwarzane przez mikrobiom jelita grubego. Witamina $\mathrm{K}$ dostępna w preparatach farmakologicznych obejmuje witaminę $\mathrm{K}_{1}$ i witaminę $\mathrm{K}_{2}$ (MK-4, MK-7) [13]. Witamina $\mathrm{K}_{1}$ może przekształcać się menachinon-4 (MK-4) i gromadzić pozakomórkowo w tkankach. Do konwersji dochodzi po doustnej suplementacji lub podaniu witaminy $\mathrm{K}_{1}$ dojelitowo. Do przekształcenia nie dochodzi w momencie pozajelitowego podania. Biodostępność jest uzależniona od postaci witaminy $\mathrm{K}$. Witamina $\mathrm{K}_{1}$ pochodząca z zielonych warzyw mocno przylega do błon komórkowych i jest mniej biodostępna od witaminy $\mathrm{K}_{1}$ zawartej w olejach roślinnych lub suplementach. Istnieje dodatnia zależność pomiędzy biodostępnością 
witaminy $\mathrm{K}_{2}$, a długością łańcucha bocznego. Normy żywienia ustalone przez IŻŻ dla populacji polskiej rekomendują dla mężczyzn $65 \mu \mathrm{g}$ a dla kobiet $55 \mu \mathrm{g}$ witaminy $\mathrm{K} /$ dobę. Witamina $\mathrm{K}$ odgrywa kluczową rolę w utrzymaniu wytrzymałości kości. Działa jako kofaktor enzymu gamma karboksylazy, która z kolei aktywuje białka zależne od witaminy $\mathrm{K}$ w kościach: OC, białko macierzy Gla (białko MGP), białko bogate w GLA, białko S i zatrzymania wzrostu swoistych 6 białek (Gas 6). Białka Gla znajdują się w płynach ustrojowych i macierzy zewnątrzkomórkowej i mają zdolność wiązania wapnia. Białko OC, które pochodzi z osteoblastów, znajduje się w kościach i chrząstkach i jest niezbędne do syntezy i regulacji macierzy kostnej. Witamina K jest potrzebna do karboksylacji osteokalcyny, która promuje przejście osteoblastów do osteocytów i również do przeprowadzenia osteoklastogenezy. Niektóre badania przekrojowe i randomizowane badania kontrolne wskazują, że stężenie witaminy $\mathrm{K}$ w osoczu dodatnio koreluje z masą kostną i ujemnie z ryzykiem pęknięcia kości [14]. Szereg przeprowadzonych badań wykazała zależność pomiędzy spożyciem witaminy $\mathrm{K}$, a stanem kośćca. Praca przeglądowa Shak K i wsp. [13] (2014), w której uwzględniono badania $z$ udziałem kobiet po menopauzie i osób starszych wskazuje na korzystne działanie dawki filachinionu $(<5 \mathrm{mg} / \mathrm{d})$ menachinionu MK-4 (45 mg/d) i MK-7 (180-360 $\mu \mathrm{g} / \mathrm{d})$ [13].

\section{Wpływ białka na stan kośćca}

Białko stanowi 50\% objętości kości i w przybliżeniu jedną trzecią jego masy. Kolagen i różne białka niekolagenowe tworzą organiczną matrycę kości, więc odpowiednia podaż w diecie wydaje się być kluczowa dla utrzymania odpowiedniej masy kostnej [15]. Optymalizacja spożycia białka jest ważnym warunkiem zachowania zdrowia osób starszych. Najnowsze wyniki badań dostarczają dowodów na to, że ilość spożywanego białka jest związana z masą mięśniową i aktywnością fizyczną Rekomendacje PROT - age group, ESPEN i ESCEO Guidelines for Postmenopausal Women zalecają spożycie przez osoby starsze 1,0-1,2 g/kg masy ciała/dobę. PROT-age sugeruje, aby posiłek zawierał 25-30 g białka, w tym 2,5-2,8 g leucyny [16]. Instytut Żywności i Żywienia (IŻŻ) rekomenduje spożycie 0,9 g/ kg masy ciała/dobę białka dla kobiet i mężczyzn $\geq 19$ roku życia [17].

Chociaż w przeszłości przyjęto, że wysokie spożycie białka wywiera szkodliwy wpływ na masę kostną, ostatnie badania na to nie wskazują [18]. W badaniu przekrojowym obejmującym 1077 kobiet, w którym spożycie białka oszacowano za pomocą kwestionariusza dotyczącego częstości spożycia pokarmów, zaobserwowano, że osoby z najniższym spożyciem białka
(<66g/d)miałyznacząconiższeBMDkręgosłupaod osób, które spożywały > $87 \mathrm{~g} / \mathrm{d}$ białka [16]. Wyniki uzyskane przez Genaro Pde S i wsp. (2015) w badaniu przeprowadzonym z udziałem kobiet w wieku powyżej 65 lat z sarkopenią i bez sarkopenii wskazują, że spożycie 1,2 g/kg masy ciała/dobę przyczynia się do wyższej masy kostnej w stosunku do grupy spożywającej 0,8-1,2 g/kg masy ciała/dobę i $<0,8 \mathrm{~g} / \mathrm{kg} /$ dobę [18]. Do podobnych wniosków doszli Wallace TC i Frankenfeld CL (2017) w metaanalizie badań z udziałem osób powyżej 18 roku życia. Zaobserwowano, że spożycie białka powyżej RDA może przyczyniać się do zapobiegania złamaniom kości. Nie zaobserwowano różnic pod względem wpływu białka zwierzęcego i roślinnego na BMD [19]. Liczba przeprowadzonych badań z udziałem osób starszych jest ograniczona, jednak wyniki metaanaliz badań z osobami w różnymi wieku potwierdzają zależność pomiędzy spożyciem białka, a gęstością mineralną kości i potwierdzają ograniczoną liczbę dowodów, które potwierdzają wpływ spożycia białka na częstość złamań [19, 15]. Zbyt niskie spożycie białka $(0,5 \mathrm{~g} / \mathrm{kg}$ masy ciała/ dobę) sprzyja obniżeniu masy kostnej [18].

\section{Wpływ wielonienasyconych kwasów tłuszczowych na stan kośćca}

Wielonienasycone kwasy tłuszczowe (PUFA) n-3 i n-6 oddziałują na stan zdrowia kości poprzez kilka mechanizmów, w tym przeciwstawne działanie do cytokin zapalnych, modulację produkcji prostaglandyn E2 (PGE2), poprawę transportu wapnia i obniżenie wydalania wapnia z moczem [20]. Wyniki badań przeprowadzonych na ludzkich komórkach kostnych, z udziałem ludzi i zwierząt wykazały zarówno korzystny, jak i negatywny wpływ w zależności od ilości i źródła PUFA [21; 22]. Uzyskane rezultaty badań zdają się wskazywać na zwiększenie masy kostnej przez EPA i DHA. W badaniu przeprowadzonym przez Järvinen R i wsp. [23] (2012) w grupie 554 kobiet o średniej wieku 68 lat zaobserwowano pozytywny związek pomiędzy spożyciem kwasów tłuszczowych n-3, a BMD kręgosłupa lędźwiowego, całego ciała, ale nie szyjki kości udowej [23]. W badaniu przeprowadzonym przez NHS przez 18 lat wśród 72000 kobiet w okresie po menopauzie zaobserwowano, że spożycie 54-142 g ciemnych ryb (miecznik, makrela, łosoś, sardynki) więcej niż raz w tygodniu zmniejszył o 33\% ryzyko złamania kości udowej w stosunku do grupy spożywającej mniej niż raz w tygodniu. W badaniu obserwacyjnym Farina EK i wsp. (2011) prowadzonym przez cztery lata z udziałem osób o średniej wieku 75 lat zaobserwowano, że wysokie (więcej niż 3 razy w tygodniu) spożycie ryb (ciemne ryby + tuńczyk, ciemne ryby, tuńczyk) bogatych w EPA i DHA może chronić przed utratą masy kostnej $(p<0,05)$ [21]. Efekt ten może 
być zależny od spożycia kwasu arachidonowego (AA). Zaobserwowano, że AA daje efekt ochronny w grupie kobiet o wysokim spożyciu EPA i DHA, a szkodliwy w grupie mężczyzn o niskim spożyciu EPA i DHA. Kwas arachidonowy może działać ochronnie na kość poprzez hamowanie NF-kB bądź szkodliwie poprzez wytwarzanie lipoksyn, które nasilają stan zapalny [20]. Wyniki dotychczas przeprowadzonych badań nie są spójne co do wpływu stosunku kwasów n-6 i n-3 na stań kośćca [21]. Brakuje danych na temat wpływu omega-3 na stan kośćca u osób z osteoporozą.

\section{Wpływ aktywności fizycznej na stan kośćca}

Siedzący tryb życia wiąże się z zwiększonym ryzykiem zachorowania na osteoporozę [24]. Aktywność fizyczna jest ważnym elementem stylu życia koniecznym dla zachowania odpowiedniej gęstości kości [25]. Spadek aktywności fizycznej uznawany jest za jeden z czynników wpływających na rozwój osteoporozy. Mężczyźni cechują się istotnie wyższą masą kostną i masą mięśniową, która jest wynikiem wyższej aktywności fizycznej w stosunku do kobiet. Zaobserwowano, że ćwiczenia fizyczne wpływają pozytywnie na gromadzenie związków mineralnych, co stymuluje tworzenie kości, jak również zmniejsza ryzyko upadków poprzez wzmacnianie masy mięśniowej [26]. Kości reagują na proces mechanotransudukcji - proces, w którym dochodzi do rozpoznania mechanicznego obciążenia przez mechanoreceptory w osteocytach. Proces osteogenezy nie następuje w wyniku statycznego wysiłku fizycznego. Istotne jest obciążenie kości poprzez aktywność fizyczną w celu uzyskania maksymalnej masy kostnej. Korzyści płynące z aktywności fizycznej w dzieciństwie są istotne dla zachowania gęstości kości w wieku starczym [24]. WHO rekomenduje u osób po 65 roku życia 150 minut aerobowej aktywności fizycznej lub 75 minut intensywnej aktywności aerobowej w ciągu tygodnia. Aktywność aerobowa powinna być wykonywana w cyklach trwających co najmniej 10 minut. WHO zaleca osobom o słabej mobilności aktywność fizyczną 3 lub więcej razy w tygodniu w celu zapobiegania upadkom, a działania wzmacniające duże grupy mięśniowe powinny być wykonywane 2 lub więcej razy w tygodniu [27]. IŻŻ rekomenduje 30-45 minut aktywności fizycznej [28]. Prot-age group rekomenduje ćwiczenia wytrzymałościowe z oporem przez 30 minut dziennie, jeśli to możliwe lub 2-3 razy w tygodniu przez 10-15 minut i spożycie $20 \mathrm{~g}$ białka po ćwiczeniach. Europen Society for Clinical Nutrition and Metabolism (ESPEN) zaleca codzienną aktywność fizyczną a ESCEO Guidelines fot postmenopausal Women regularną aktywność fizyczną, 3-5 razy w tygodniu i spożycie białka w okolicach ćwiczeń [16]. Przegląd systematyczny badań prowa- dzonych z udziałem kobiet po menopauzie wykazał, że ćwiczenia siłowe oraz program ćwiczeń aerobowych i siłowych skutecznie poprawia i utrzymują masę kostną. Wyniki przeglądu systematycznego sugerują, że w celu osiągnięcia najlepszych efektów treningu wytrzymałościowego potrzebne są trzy sesje w tygodniu i dwa zestawy ćwiczeń w jednej sesji. Przegląd systematyczny wykazał, że u mężczyzn w średnim wieku i starszych mężczyzn najskuteczniejszym treningiem zapobiegającym utracie masy kostnej jest trening siłowy [25]. Wyniki metaanalizy przeprowadzonej przez Simas V i wsp. [29] (2017), która obejmowała 629 kobiet po menopauzie zaobserwowano, że ćwiczenia wykonywane w wodzie mogą mieć korzystniejszy wpływ na gęstość mineralną kośćca w kręgosłupie lędźwiowym i karku w stosunku do ćwiczeń wykonywanych na lądzie. Nie zaobserwowano różnić pomiędzy wpływem ćwiczeń wykonywanych na lądzie, a ćwiczeniami wykonywanymi w wodzie na BMD kości udowej [29]. Według Bolam KA i wsp. [30] (2013) i Gomez Cabello A i wsp. [31] (2012) spacery nie są skuteczne w zapobieganiu osteoporozie, ponieważ zapewniają niewielkie obciążenie szkieletu powyżej obciążenia grawitacji $[30,31]$.

\section{Podsumowanie}

Styl życia jest istotnym elementem zapobiegania osteoporozie. W celu zmniejszenia ryzyka zachorowania na osteoporozę konieczna jest edukacja żywieniowa od dzieciństwa na temat wpływu podaży witaminy D, K, wapnia, białka oraz aktywności fizycznej na gęstość mineralną kości. Odpowiednia podaż witaminy $\mathrm{K}$ oraz białka może zostać dostarczona z żywnością. Brakuje dokładnych danych na temat wpływu omega-3 na stan kośćca u osób z osteoporozą. Koniecznym zdaje się być przeprowadzenie badań, w których suplementowano by kwasy tłuszczowe omega-3 u osób z osteoporozą.

\section{Piśmiennictwo}

1. WHO (2014). Scientic group on the assesment of osteoporosis at primary health cery level. https://www.who.int/chp/ topics/Osteoporosis.pdf [Data dostępu: 26.04.2019 r].

2. Hill TR, Aspray TJ. The role of vitamin D in maintaining bone health in older people. Ther Adv Musculoskel Dis. 2017; 9(4): 89-95.

3. Catalano A, Martino G, Morabito N, Scarcella C, Gaudio A, Basile G, Lasco A. Pain in Osteoporosis: From Pathophysiology to Therapeutic Approach. Drugs Aging. 2017; 34(10): 755-765.

4. Weaver JP, Olsson K, Sadasivan R, Modi A, Sen S. Reasons for Not Treating Women with Postmenopausal Osteoporosis with Prescription Medications. Physicians' and Patients' Perspectives. J Womens Health (Larchmt). 2017; 26(12): 1302-1311.

5. Włodarek D. Znaczenie diety w zapobieganiu osteoporozie. Endokrynol Otyłość. 2009; 5(4): 245-253.

6. Platta A. Rola żywienia w profilaktyce i leczeniu osteopenii i osteoporozy u kobiet. ZN AMG. 2014; 89:16-28. 
7. Marcinowska-Suchowierska E, Sawicka A. Wapń i witamina D w prewencji złamań osteoporotycznych, Post Nauk Med. 2012; 25(3):273-279.

8. Brech GC, Ciolac EG, Peterson MD, D'Andre'a Greve JD. Serum 25-hydroxyvitamin D levels are associated with functional capacity but not with postural balance in osteoporotic postmenopausal women. Clinics. 2017; 72(1): 11-16.

9. Białkoz-Kalinowska I, Konstantynowicz J, Abramowicz P, Piotrowska- Jastrzębska J. Dieta w profilaktyce osteoporozy- zalecenia i kontrowersje. Pediatr Med. Rodz. 2013; 9(4): 350-356.

10. Wojtasik A, Jarosz M, Stoś K. Składniki mineralne. W: Jarosz M (red). Normy żywienia dla populacji polskiej-nowelizacja. Warszawa: IŻŻ; 2017. 203-237.

11. Włodarek D, Głąbska D, Kołota A, Adamczyk P, Czekajło A, Grzeszczak W, Drozdzowska B, Pluskiewicz W. Calcium intake and osteoporosis: the influence of calcium intake from dairy products on hip bone mineral density and fracture incidence- a population-based study in women over 55 years of age. Public Health Nutrition. 2012; 17(2): 383-389.

12. Dardzińska J, Chabaj-Kędroń H, Małgorzewicz S. Osteoporoza jako choroba społeczna i cywilizacyjna - metody profilaktyki. Hygeia Public Health. 2016; 51(1): 23-30.

13. ShakK, Gleason L, Villareal DT. Vitamin Kand bone health in older adults. J Nutr Gerontol Geriatr. 2014; 33(1): 10-22.

14. Palermo A, Tuccinardi D, D'Onofrio L, Watanabe M, Maggi D, Maurizi AR, Greto V, Buzzetti R, Napoli N, Pozzilli P, Manfrini S. Vitamin K and osteoporosis: Myth or reality? Metabolism. 2017; 70: 57-71.

15. Shams-White MM, Chung M, Du M, Fu Z, Insogna KL, Karlsen MC, LeBoff MS, Shapses SA, Sackey J, Wallace TC, Weaver CM. Dietary protein and bone health: a systematic review and meta-analysis from the National Osteoporosis Foundation. Am J Clin Nutr. 2017; 105(6): 1528-1543.

16. Bauer JM, Diekmann R. Protein and Older Persons. Clin Geriatr Med. 2015; 31(3): 327-38.

17. Jarosz M, Charzewska J, Chwojnowska Z, Wajszczyk B. Białka. W: Jarosz M (red). Normy żywienia dla populacji polskiej-nowelizacja. Warszawa: IŻŻ; 2017. 40-54.

18. Genaro Pde S, Pinheiro Mde M, Szejnfeld VL, Martini LA. Dietary protein intake in elderly women: association with muscle and bone mass. Nutr Clin Pract. 2015; 30(2): 283-9

19. Wallace TC, Frankenfeld CL. Dietary Protein Intake above the Current RDA and Bone Health: A Systematic Review and Meta-Analysis. J Am Coll Nutr. 2017; 36(6): 481-496.

20. Farina EK, Kiel DP, Roubenoff R, Schaefer EJ, Cupples LA, Tucker KL. Protective effects of fish intake and interactive effects of long-chain polyunsaturated fatty acid intakes on hip bone mineral density in older adults: the Framingham Osteoporosis Study. Am J Clin Nutr. 2011; 93(5): 1142-51.

21. Longo AB, Ward WE. PUFAs, Bone Mineral Density, and Fragility Fracture: Findings from Human Studies. Adv Nutr. 2016; 7(2): 299-312.
22. Dong $H$, Hutchins-Wiese $H$, Kleppinger A, Annis $K$, Liva E, Lammi-Keefe C, Durham H, Feinn R, Kenny AM. Effects of Omega-3 Polyunsaturated Fatty Acid Supplementation on Bone Turnover in Older Women. Int $\mathrm{J}$ Vitam Nutr Res. 2014;84(3-4): 124-32.

23. Järvinen R, Tuppurainen $M$, Erkkilä AT, Penttinen $P$, Kärkkäinen M, Salovaara K, Jurvelin JS, Kröger H. Associations of dietary polyunsaturated fatty acids with bone mineral density in elderly women. Eur J Clin Nutr. 2012; 66(4): 496-503.

24. MacKnight JM. Osteopenia and Osteoporosis in Female Athletes. Clin Sports Med. 2017; 36(4): 687-702.

25. Zhu K, Prince RL. Lifestyle and Osteoporosis. Curr Osteoporos Rep. 2015; 13: 52-59.

26. Gryczyńska B, Iska M, Gryczyńska A, Kasprzak M, Budzyń-Napierała M. Pierwiastki, rośliny i aktywność fizyczna w profilaktyce oraz leczeniu osteoporozy. Post. Fitoter. 2014; 2: 76-83.

27. WHO (2011). Global Recommendations on Physical Activity for Health. 65 years and bove. https://www.who.int/dietphysicalactivity/global-PA-recs-2010.pdf [Data dostępu: 26.04.2019 r.].

28. Piramida zdrowego żywienia i aktywności fizycznej. IŻŻ. 2016 https://ncez.pl/upload/piramida-dla-dzieci-imlodziezy-opis.pdf [Data dostępu: 26.04.2019 r.].

29. Simas V, Hing W, Pope R, Climstein M. Effects of waterbased exercise on bone health of middle-aged and older adults: a systematic review and meta-analysis. J Sports Med. 2017; 8: 39-60.

30. Bolam KA, van Uffelen JG, Taaffe DR. The effect of physical exercise on bone density in middle-aged and older men: a systematic review. Osteoporos Int. 2013;24(11):2749-62.

31. Gomez-Cabello A, Ara I, Gonzalez-Aguero A, Casajus JA Vicente-Rodriguez $G$. Effects of training on bone mass in older adults: a systematic review. Sports Med. 2012;42(4): 301-25.

Artykuł przyjęty do redakcji: 07.08.2018.

Artykuł przyjęty do publikacji: 29.04.2019.

Źródło finansowania: Praca nie jest finansowana z żadnego źródła. Konflikt interesów: Autorzy deklarują brak konfliktu interesów.

\section{Adres do korespondencji:}

Dorota Gumiela

Katedra i Zakład Biochemii i Biologii Molekularnej, Uniwersytet Medyczny im. Karola Marcinkowskiego w Poznaniu

ul. Święcickiego 6

60-842 Poznań

tel. (61) 8546509

e-mail:dgumiela@ump.edu.pl 